\section{Fishing with otters - a fading tradition}

For countless generations, fishermen in southern Bangladesh have bred otters Lutra (= Lutrogale) perspicillata and used them to chase fish into their nets. Once a widespread practice passed from father to son throughout many communities in Asia, this traditional use of wild animals survives only in one district in Bangladesh.

I tracked this fishing practice through scientific literature and anecdotal accounts. Those working with otters in the world's zoos know that they are very difficult to breed. I was certain that the fishermen of Bangladesh must know some of the answers to captive otter reproduction. So, in February 1997 I travelled to Bangladesh to find out.

In the Sunderbans, the brackish delta of the Ganges River, I found a group of nomadic otter fishermen. They lived with their families in a covered area in the bows of their long, narrow boats and kept a pair of otters and their cubs in portable cages in the stern. To fish, they lowered a mesh net beside the boat and tied a long rope to a harness on each adult otter and to long bamboo poles at both sides of the net. The tethered adult otters chased fish into the net while the cubs swam freely, 'learning' the fishing technique. As a reward, they received some of the catch and a drink from the fishermen's own freshwater supply.

From the fishermen, I learned about breeding smooth otters. In a situation that encourages mate choice, the otters were paired, split up and re-paired through trades with other fishermen until, eventually, a compatible breeding pair was established, producing one litter a year for the rest of their lives. Although occasionally succumbing to a crocodile, disease or infection from a too-tight harness, the captive otters I saw in the Sunderbans were in good condition.

The distressing side of the fishing-otter story only became apparent further north in the permanent otter-fishing villages in Narail District. As one of the few Westerners to visit this area, I navigated through hordes of onlookers to interview a number of fishing families. In the villages, I saw pairs of often sick-looking otters tethered to small cages, was told about litters that had died and saw a few dying cubs firsthand. As I investigated further, $I$ found the reason. For much of the year the fish were gone. This was not only a result of unsustainable overfishing, a worldwide problem, but something even worse, beyond the communities' control. The rivers were drying up. As more and more water was extracted for agriculture and other uses from the Ganges River in India, what were once year-round rivers flowing through the Narail region were now seasonal streams, at best. Ironically, this issue of the conflicting demands on water resources had been the focus of the White Oak/World Bank conference on Mainstreaming Freshwater Biodiversity in Water Development Projects that we hosted at White Oak just a week prior to my departure for Bangladesh. Now, I had the sad opportunity to see these effects in otter terms.

Otters are very good at catching fish, if there are fish to be had. But, now, these Bangladeshi villagers had to buy fish to feed the otters for half of the year. At $1 \mathrm{~kg}$ of fish/otter/day, it costs nearly $\$ 2$ daily to feed a pair of otters - a princely sum in Bangladesh, and more than it costs the fishermen to feed their entire families. Only the richest fishermen could afford the trek to the Sunderbans to fish during the dry season. The rest stayed behind in Narail, and tried to keep their otters and families alive until the rains came, the rivers flowed and the fish returned.

Of the five fishing collectives that I interviewed in Narail District, none of the fishermen said that their sons would continue this practice. They would go to the city and, if they were lucky, start a small business. And if not, they would pedal a rickshaw through a hard and shortened life. And, when they died, so too would die one more irreplaceable chunk of the world's cultural and biological diversity.

\section{Pat Foster-Turley \\ White Oak Conservation Center E-mail:102625.1025@compuserve.com}

3823 Owens Road, Yulee, Florida 32097, USA 